\title{
Advective heat transfer and fabric development in a shallow crustal intrusive granite - the case of Proterozoic Vellaturu granite, south India
}

\author{
Dilip SAHA* and SukAnya Chakraborti \\ Indian Statistical Institute, Geological Studies Unit, 203 B. T. Road, Kolkata 700 108, India. \\ *e-mail:dsaha@isical.ac.in
}

\begin{abstract}
Syntectonic plutons emplaced in shallow crust often contain intermediate- to low-temperature deformation microstructures but lack a high-temperature, subsolidus deformation fabric, although the relict magmatic fabric is preserved. The Proterozoic Vellaturu granite emplaced at the eastern margin of the northern Nallamalai fold belt, south India during the late phase of regional deformation has a common occurrence of intermediate- to low-temperature deformation fabric, superimposed over magmatic fabric with an internally complex pattern. But high-T subsolidus deformation microstructure and fabric are absent in this pluton. The main crystal plastic deformation and fluid enhanced reaction softening was concentrated along the margin of the granite body. Resulting granite mylonites show Y-maximum $c$-axis fabric in completely recrystallized quartz ribbons, dynamic recrystallization of perthites, and myrmekite indicative of fabric development under intermediate temperature $\left(\sim 500-400^{\circ} \mathrm{C}\right)$. The weakly-deformed interior shows myrmekite, feldspar microfracturing and limited bulging recrystallization of quartz. The abundance of prism subgrain boundaries is indicative of continuing deformation through low-temperature $\left(\sim 300^{\circ} \mathrm{C}\right)$. The relative rates of cooling influenced by advective heat transfer and deformation of the pluton seem to control the overall subsolidus fabric development. The rapid advective heat transfer from the interior in the early stages of subsolidus cooling was followed by slow cooling through intermediate temperature window as a well-developed phyllosilicate rich mylonitic skin around the granite body slowed down conductive heat loss. Low-T crystal plastic deformation of quartz was effected at a late stage of cooling and deformation of the shallow crustal granite body emplaced within the greenschist facies Nallamalai rocks.
\end{abstract}

\section{Introduction}

Fabric in granitic rocks is important as it has direct bearing on the emplacement processes, regional deformation and post-emplacement history. Emplacement of granitic bodies is usually linked to orogenic processes though exceptions occur in rift-related anorogenic granites (Pitcher 1997). In case of multi-pulse granitic plutons the fabric often transects pulse boundaries suggesting poor memory of the early, truly magmatic fabric representing Newtonian viscous flow (Paterson et al 1998). On the other hand, alignment of subhedral to euhedral zoned plagioclase or mafic minerals such as hornblende and biotite is often cited as indicative of melt present flowage (magmatic flow or submagmatic flow with $<20 \%$ melt; Hutton 1988; Paterson et al 1989). The magmatic fabric as frozen in rocks usually represents the late stage of solidification and deformation of a crystalmush (Paterson et al 1998), and the rheology is dependent among other things, on the ratio of mineral crystals to melt, spatial distribution of the phases and strain rate (Vigneresse et al 1996;

Keywords. Advective heat transfer; granite pluton; deformation microstructures; rate of cooling; quartz $c$-axis fabric; Nallamalai fold belt. 
Vigneresse 2004). The alignment of feldspar phenocrysts and clusters of biotite in undeformed to weakly-deformed felsic matrix is referred to as magmatic fabric in this paper.

As the cooling magma body acquires adequate non-Newtonian viscosity the stage is set for regional and/or emplacement-related strain increments to be frozen in fabrics. Although one may expect a continuum of submagmatic through high-temperature solid state to moderate and low-temperature deformation fabric in syntectonic plutons, the rate of cooling of magma pulses compared to the rate of deformation may lead to a hiatus in fabric record (c.f. Paterson and Tobisch 1992; Tribe and D'Lemos 1996). The rheological behaviour of granitic magmas changes progressively due to changes in crystal content, crystal density and differing growth rates. Moreover, as a chamber may be fed in batches through dikes, diapirism, porous flow, etc., the influence of petrographic variation and age of different components within a pluton is an important factor in assessing fabric evolution.

Although in some migmatitic bodies the transition from high-temperature deformation fabric to magmatic fabric has been documented (e.g., Mainprice et al 1986), others lack hightemperature deformation fabrics (e.g., Tribe and D'Lemos 1996). Deformation microstructure and texture in quartz and feldspar appear to be predictably influenced by ambient deformation temperature (Simpson 1985; Gapais and Barbarin 1986; Paterson et al 1989; Tullis and Yund 1985; Pryer 1993; Stipp et al 2002). Thus documentation and interpretation of fabric in well-studied individual plutons contribute toward a better resolution of the general debate surrounding pluton cooling and the effect of regional deformation in syn-tectonic to late-tectonic shallow crustal plutons. While it has been shown that fabrics in granites have poor memory of early viscous flow (e.g., Paterson et al 1998), the nature of internal magmatic fabric in syntectonic plutons may vary considerably depending on the rheological behaviour of the intrusive body at the late stage of solidification relative to the host rock, strain rate relative to rate of cooling, and strain partitioning apart from internally driven processes such as magma surges. Subsolidus deformation history is also influenced by strain rate relative to rate of cooling, strain partioning and fluid enhanced mineralogical changes. With these issues in mind we examine the Vellaturu granite body which was emplaced along the eastern margin of the Proterozoic Nallamalai fold belt in southeastern India during the late phase of regional deformation.

Cooling and solidification of a pluton is a slow process and high-T subsolidus changes must have been influenced by residual aqueous fluids in a largely solidified igneous intrusive in a relatively cooler, shallow crustal host rock. Thermal models usually take into account conductive heat transfer from the pluton into the host rock. In this work we suggest that advective heat transfer may also play a significant role in down temperature fabric development in shallow crustal plutons as in the case of the Vellaturu granite.

\section{Regional geology}

The Proterozoic Nallamalai fold belt (NFB) representing the eastern half of the Cuddapah basin in southeastern India is bordered by the Nellore schist belt (NSB) in the east. The latter in turn gives way to the high grade Eastern Ghats granulite belt (EGGB) in the northeastern domain of the NSB (figure 1; Ramakrishnan et al 1998). The EGGB was tectonically juxtaposed against the NSB with a component of thrust movement along the contact. The NSB in turn was thrust over the NFB along an easterly dipping thrust (Narayanswami 1966; Meijerink et al 1984; Nagaraja Rao et al 1987; Venkatakrishnan and Dotiwala 1987; Saha 2002, 2004).

A number of granitic bodies occur close to the NFB-NSB contact on either side of the contact in the northeast NFB (figure 2). In contrast, the central and western part of the NFB is devoid of any intrusive granitic bodies. Of the granitic bodies along the northeastern margin, the Vinukonda granite or Shivapuram granite are hosted by a suite of quartz-feldspar mylonitic gneiss, biotite gneiss with pockets of quartz-mica schist and pegmatite belonging to the NSB. A sequence of metasediments, namely quartzites and phyllites intercalated with thin impure marble bands, belonging to the Nallamalai Group, has been intruded by the Vellaturu granite along the eastern margin of the Nallamalai fold belt (Meijerink et al 1984; Nagaraja Rao et al 1987; Saha 2002).

Earlier work supports a multi-stage contractional deformation of the NFB and the adjoining NSB (Meijerink et al 1984; Saha 2002; cf. Nagaraja Rao et al 1987). Three phases of deformation have been identified in the Nallamalai rocks of the northern NFB (Saha 2002). While tightto-isoclinal folds, an associated slaty cleavage and local mylonite development represent $\mathrm{D}_{1}$ structures, $\mathrm{D}_{2}$ structures include NE trending open folds with variable plunge indicating control of large domal structures, and a steep crenulation cleavage in phyllites and other schistose rocks. $\mathrm{D}_{1}$ and $\mathrm{D}_{2}$ structures are overprinted by roughly $\mathrm{E}-\mathrm{W}$ trending $\mathrm{D}_{3}$ folds and cleavage which are more restricted in occurrence, for example, in the Vami Konda range (table 2 in Saha 2002). A number 


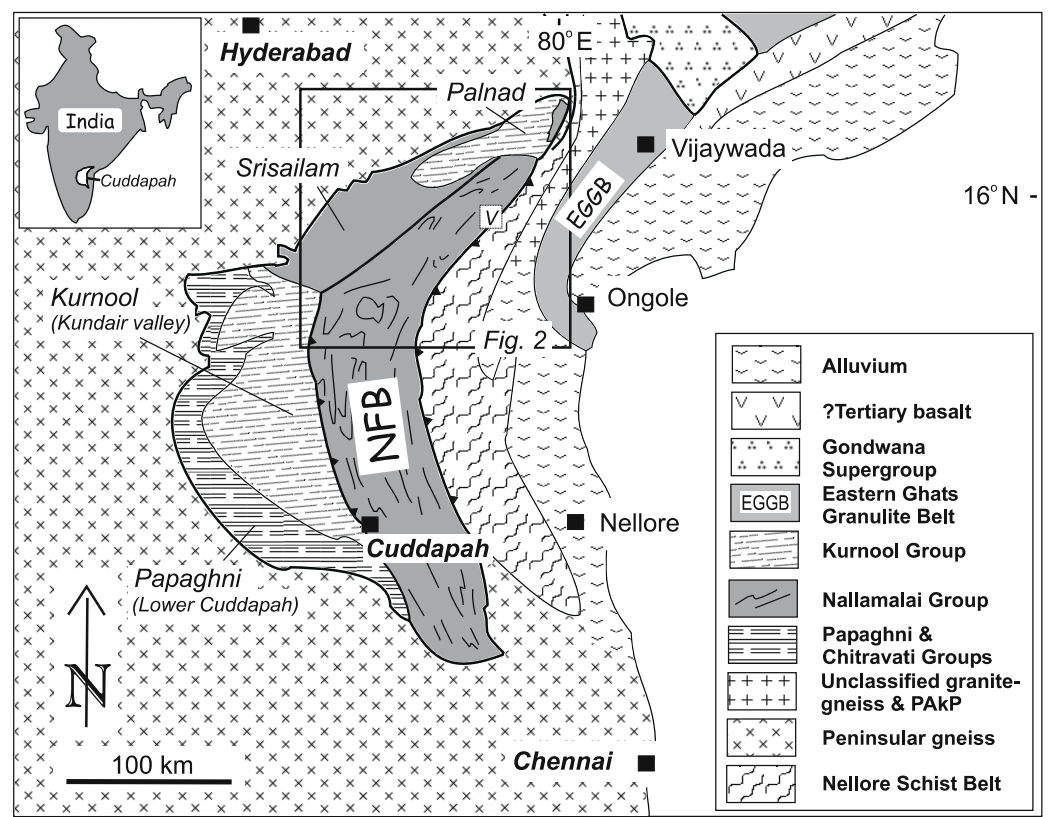

Figure 1. Regional geological map of southeastern India showing the Nallamalai fold belt (NFB) in relation to the Nellore schist belt (NSB), Prakasam alkaline province (PAkP) and the Eastern Ghats granulite belt (EGGB). V for Vellaturu granite body; details in figure 3 .

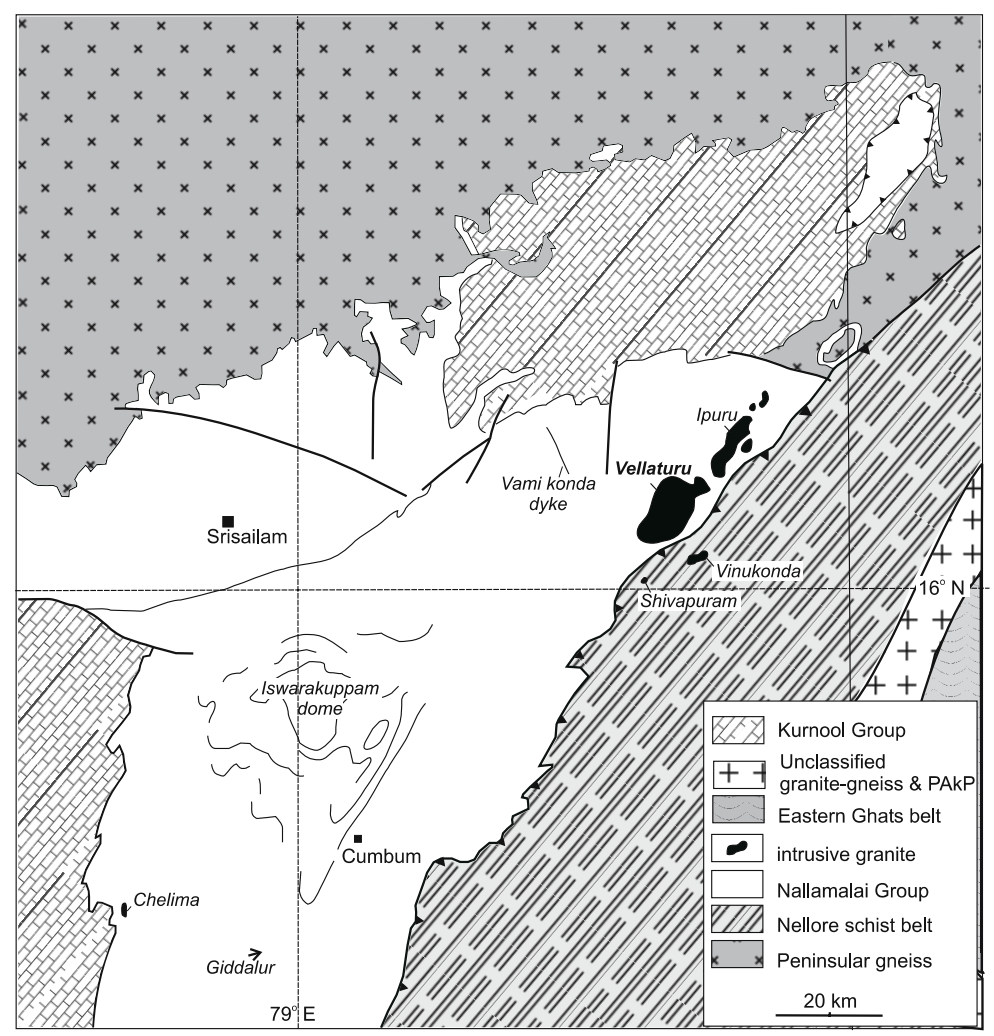

Figure 2. Granitic intrusives in the northern Nallamalai fold belt. Note elongation of individual bodies parallel to regional trend and paucity of granitic intrusives in the western part of the NFB.

of $\mathrm{E}-\mathrm{W}$ faults with a component of dextral strike slip displacement and representing $\mathrm{D}_{3}$ deformation are also mapped along the eastern margin of the NFB (Saha 2002; Saha and Chakraborty 2003).
One of these faults close to the southern margin of the Vellaturu granite offsets the boundary between the NFB and NSB (figure 3 ). The $\mathrm{D}_{3}$ deformation in the northern NFB is associated with overall 

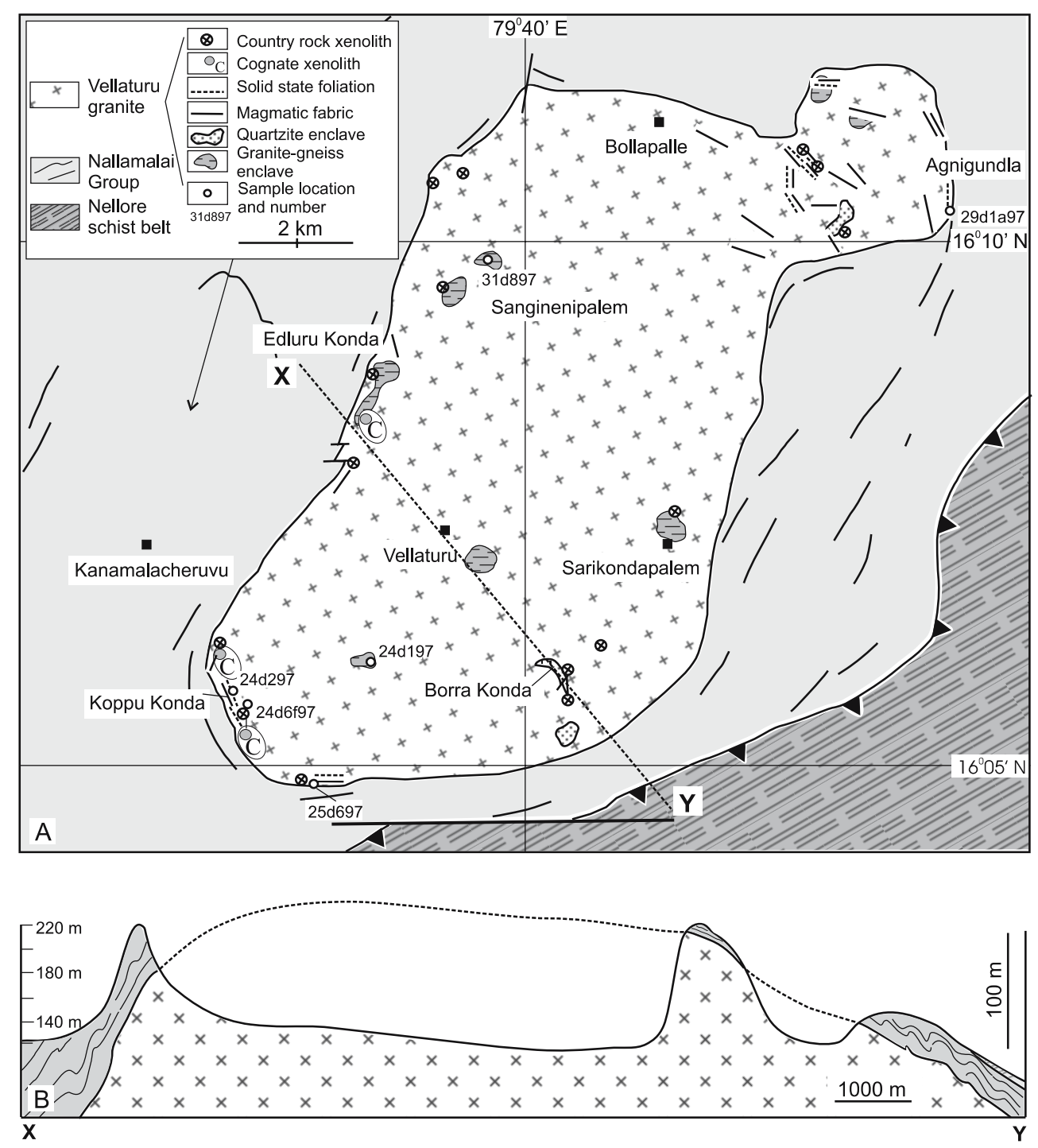

Figure 3. (A) Foliation trajectory in the Vellaturu granite and surrounding rocks. (B) Structural cross section across the granite body highlighting the presence of a steeper western flank.

subhorizontal ESE-WNW shortening and one set of NNW-SSE trending shear planes is kinematically feasible under such bulk strain. Although magmatic fabric in the Vellaturu granite is internally complex, as described in the next section, one modal orientation of steep foliation has the NNW trend.

The earlier deformation $\left(D_{1}\right.$ and $\left.D_{2}\right)$ affected the Nallamalai Group of rocks in the NFB and rocks of the NSB. This deformation, constrained by age of intrusive bodies, may be older than $\sim 1440 \mathrm{Ma}$ (Crawford and Compston 1973; Gupta et al 1984; Chalapathi Rao et al 1999). This early contractional deformation along the eastern margin of the Indian craton is possibly associated with early Mesoproterozoic pre-Rodinia convergence of continental fragments (Rogers and Santosh 2002). A later deformation affecting the Nallamalai group, as well as the overlying Neoproterozoic Kurnool
Group in Kundair valley and Palnad area has not so far been directly constrained by any radiometric dates. But the regional geologic set-up and available dates from the neighbouring regions indirectly suggest superimposed deformation of these rock groups during the Grenville and/or PanAfrican convergence (Saha and Chakraborty 2003; Dobmeier et al 2006).

With an outcrop size of $\sim 200 \mathrm{~km}^{2}$, the Vellaturu granite is apparently the largest intrusive in the NFB. Rb-Sr model age for the Vellaturu granite is given as $\sim 1575 \mathrm{Ma}$ (Agnigundla granite of Crawford and Compston 1973). Similar dates have been reported for the Vinukonda granite occurring in the NSB c. $10 \mathrm{~km}$ east of Vellaturu (Rb-Sr isochron age $\sim 1600 \mathrm{Ma}$, Gupta et al 1984; $\mathrm{U}-\mathrm{Pb} \mathrm{Zr}$ discordia age $\sim 1580 \mathrm{Ma}$, Dobmeier et al 2006). The Vellaturu granite has been interpreted either as representing a reactivated basement 


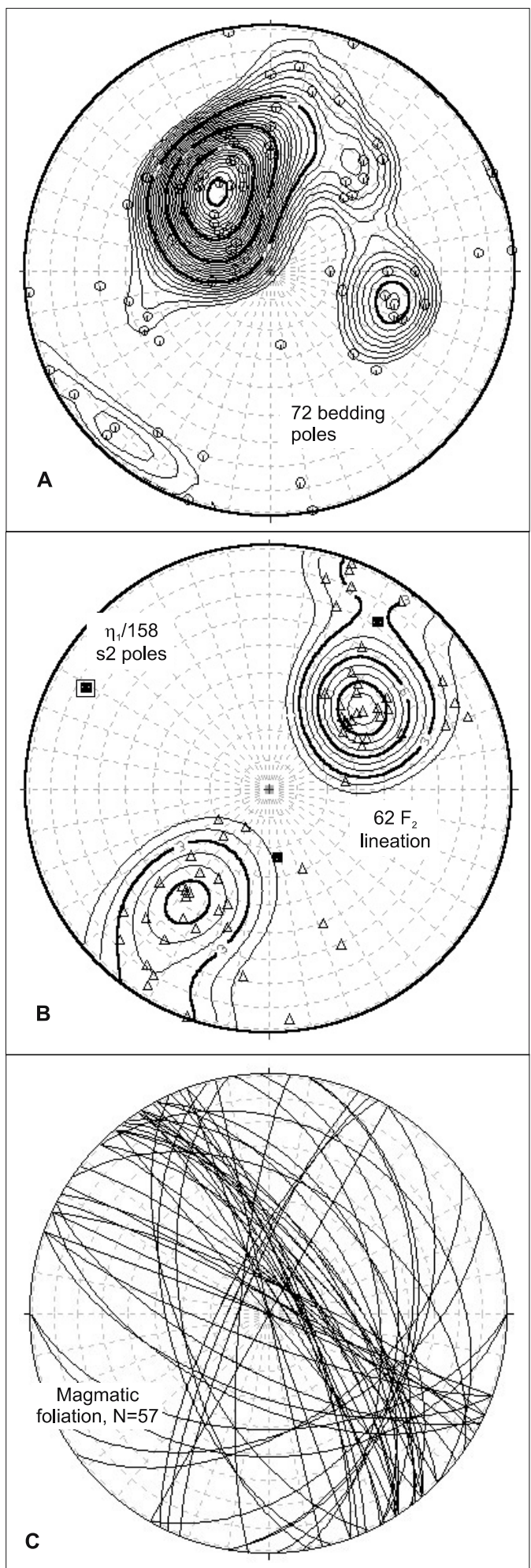

Figure 4. Lower hemisphere equal area plots showing orientation of structural elements from domal upwarp of wall rocks around the Vellaturu granite. (A) Bedding poles; contours as multiples of $\sigma$ beginning at $0.25 \sigma$ where $3 \sigma=\mathrm{E}$, expected value for uniform distribution. (B) $\mathrm{F}_{2}$ lineation; contours as multiples of $\sigma$ beginning at $1 \sigma . \eta_{1}$ corresponds to the orientation of maximum eigen vector for $158 \mathrm{crenu}-$ lation cleavage $\left(\mathrm{S}_{2}\right)$ poles and is perpendicular to the girdle through $\mathrm{F}_{2}$ lineation. (C) Complex pattern of magmatic foliation in the Vellaturu granite. Note one NW-SE trending modal orientation. circumscribed by a metasedimentary cover (Nagaraja Rao et al 1987), or as intrusive into the surrounding Nallamalai rocks (Narayanswami 1966; Ramam and Murthy 1997; Saha 2002). A brief review of the field relations which demonstrate intrusive relationship is given below.

\subsection{Vellaturu granite and its envelope}

The sub-elliptical Vellaturu granite outcrop has a NE-SW elongation parallel to the regional strike of the fold belt in the northern Nallamalai fold belt (figures 1-2). The contact with the surrounding Nallamalai Group of metasediments dips steeply away from the centre of the granite body. The bedding, $S_{0}$ and phyllitic cleavage, $S_{1}$ in the enclosing metasediments appear to wrap around the granite body except where the immediate contact is well exposed and the foliation is mapped as having a discordant relation with the margin of the granite body (figure 3; Saha 2002). The orientation distribution of both $S_{0}$ and $S_{1}$ in the envelope suggests an elongated asymmetric dome form of the surrounding metasedimentary strata. The granite body occurring in the core of the asymmetric dome has relatively gentler eastern flank, compared to its western, northern and southern margin (figure 3B). Exposed contacts with the host Nallamalai rocks show that the contact walls dip outward into the surrounding rocks.

The main structural elements in the metasedimentary envelope are a set of early inclined to reclined folds $\left(\mathrm{F}_{1}\right)$ and associated slaty/phyllitic cleavage, overprinted and reoriented by nearupright, NE-SW trending $\mathrm{F}_{2}$ folds (regional $\mathrm{D}_{2}$ deformation, Saha 2002). The latter is associated with a steep NE-SW trending crenulation cleavage in phyllites and micaceous quartzites (figure 4). Plots of fold axis lineation $\left(\mathrm{F}_{2}\right)$ form a NE-SW steep girdle (figure $4 \mathrm{~B}$ ) consistent with $\mathrm{F}_{2}$ plunge reversal over the long axis of the outcrop of the granite body. A synformal depression of the envelope has been mapped only on the northwestern flank of the granite body (figure 3 ). In addition, near the thrust contact between the Nellore schist belt and Nallamalai fold belt (figure 2) the Nallamalai quartzites show well-developed mylonitic fabric broadly coeval with the $\mathrm{D}_{1}$ deformation (Saha 2002). The stretching lineation associated with the quartz mylonites in the footwall of the southeast dipping boundary thrust has a gentle plunge toward southeast. Oblique grain shape fabric in dynamically recrystallized quartz in section perpendicular to mylonitic foliation and parallel to stretching lineation (XZ section) indicates a component of top-to-NW movement along the boundary thrust (Saha 2002). 


\subsection{Enclaves and xenoliths}

The Vellaturu granite consists mainly of coarse, massive, light gray biotite granite, a darker (graygreen) porphyritic granite with alkali feldspar phenocrysts and in addition locally developed pegmatite bands and veins cutting the other components. Although the spatial relationship in individual exposures suggests that the porphyritic variety is a relatively older component, the map distribution is not exactly like a multi-pulse composite pluton (cf. Ardara pluton, Papoose Flat pluton; Paterson and Vernon 1995). Exposures along the margin of the Vellaturu granite and those in the vicinity of the major country rock enclaves at Barra Konda and southwest of Agnigundla (figure 3) contain abundant decimeter-to-metre sized country rock xenoliths. Quartzite xenoliths in granite exposures north of Borra Konda show minor folds on foliation in quartzite, while the host granite is massive. The minor folds in the quartzite xenoliths are comparable in style to $\mathrm{F}_{2}$ minor folds in the surrounding Nallamalai rocks (Saha 2002).

These xenoliths derived from the quartzitephyllite sequence of the surrounding Nallamalai rocks show significant metasomatic alteration, particularly by way of introduction of subhedral alkali feldspar and biotite in psammitic protolith fragments. Small microgranitoid enclaves, usually biotite rich and with diffuse margin with the surrounding gray granite are also locally observed.

At Barra Konda, the massive gray granite with occasional almandine has a spotted appearance with a random dissemination of $\mathrm{cm}$-scale green elliptical patches (figure 5B) containing decussate aggregates of chlorite, biotite and quartz apparently formed by contact metamorphism of pelitic protolith and then cannibalized by the invading magma pulse. It is expected to have a contact aureole around an intrusive granite body of large dimension. But the general refractory nature of the quartzite in the immediate contact zone and possibly dislocation of the contact zone material by stoping and their subsequent incorporation in the later pulses of granitic magma led to apparent absence of any perceptible contact aureole around the Vellaturu granite.

The discordance between the foliation in the surrounding Nallamalai rocks and margin of the granite and common occurrence of host rock enclaves possibly dislodged by stoping of host rock indicate intrusive relationship and post- $\mathrm{D}_{2}$ timing of emplacement (Saha 2002). However, the overall NE-SW elongation of the Vellaturu granite and nearby granite bodies in the northern NFB (figure 2) and the internally complex magmatic fabric as described below, may relate to D3 deformation
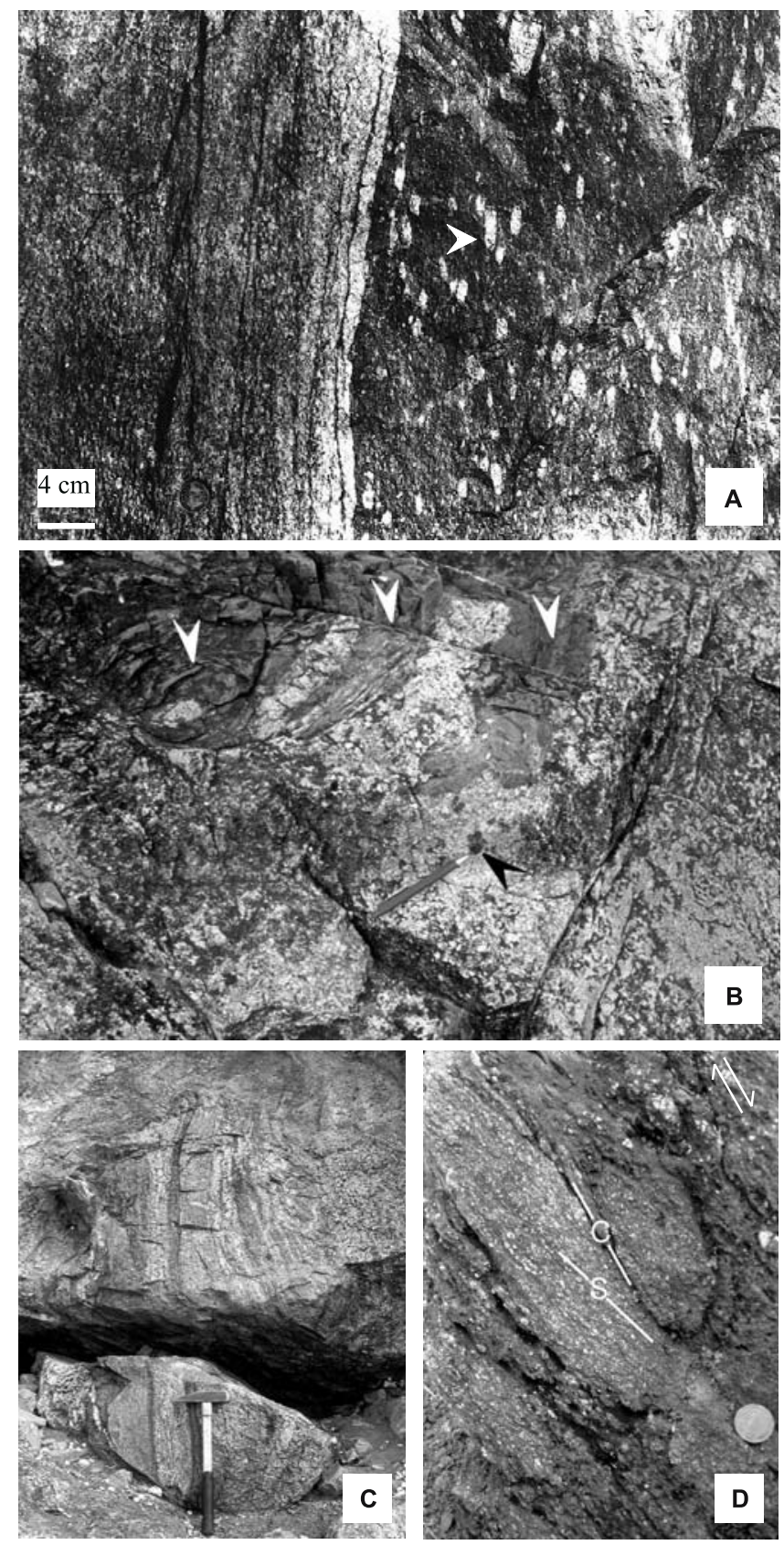

Figure 5. Macroscopic fabric in the Vellaturu granite. (A) Transition from foliated porphyritic granite to banded gray granite (left half of photo; after Saha 2002). Note alignment of feldspar phenocrysts (white arrow). (B) Psammitic enclave (white arrows) invaded by tongues of gray granite, Barra Konda. Note that small xenoliths derived from the contact aureole appear as dark spots (black arrow). (C) Schlieren around a metre-sized psammitic enclave, Koppu Konda. (D) S-C fabric in granite mylonite, southern margin of the Vellaturu granite. View looking East on vertical joint perpendicular to mylonitic foliation and parallel to stretching lineation (XZ section).

and a rheological decoupling between the granite and the surrounding Nallamalai rocks undergoing the late deformation. Based on dynamic analysis of calcite e-twins Chakraborty and Saha (2005) suggested overall ESE-WNW compression during 
the late deformation which affected the Nallamalai group and the younger Kurnool group. E-W trending faults with a right-lateral strike slip component have been mapped in the Vellaturu area (figure 3A) and further north (Saha 2002; Saha and Chakraborty 2003). As $\mathrm{D}_{1}$ and $\mathrm{D}_{2}$ structures are reoriented/displaced in the vicinity of these faults, these are likely to be related to $\mathrm{D}_{3}$ regional deformation and may have control on the emplacement and overall NE-SW elongation of the Vellaturu granite.

\section{Petrographic variation and macroscopic fabric}

The Vellaturu granite samples are dominantly in the granite field with some variation into the alkalifeldspar-granite field or rarely into granodiorite field (Strekeisen 1976). Fabric development, related to late stage solidification and deformation of a crystal-mush (e.g., Vigneresse et al 2004), in the Vellaturu granite is spatially heterogeneous (figure 3). Such magmatic fabric (sensu Paterson et al 1998 ) is more common in the porphyritic variety or its gradation to gray biotite granite.

The long axis of subhedral K-feldspar and some plagioclase phenocrysts measure up to $2 \mathrm{~cm}$ in the porphyritic variety. These generally show a preferred orientation which defines the magmatic fabric (figure 5A; Paterson et al 1998). Magmatic fabric, a foliation and locally a lineation on foliation, is more intense where biotite flakes or elongated clusters of mafic minerals are aligned subparallel to feldspar long axis. Magmatic foliation in the Vellaturu granite shows steep-tomedium dip with spread in foliation azimuth (Saha 2002). A NNW-SSE trending modal orientation of the foliation, discordant with respect to NE$\mathrm{SW}$ trending $\mathrm{D}_{2}$ Vellaturu domal structrue is clear. However, the internally complex magmatic fabric (figure 4C) suggests

- a significant degree of rheological decoupling between host rock and the Vellaturu granite;

- increased influence of internally driven processes, e.g., magma surges, in generating the variable and discordant orientation of the internal fabric (Paterson et al 1998).

Although the gray granite constituting the greater part of the Vellaturu outcrop is generally massive, variation in grain size and proportion of mafic minerals in adjacent bands locally define a gneissic foliation. Additionally the neighbourhood of large stoped blocks of metasedimentary country rock is marked by schlieren (figure 5C). Such metre-todecametre size stoped blocks are common along the border of the Vellaturu granite.
Field studies reveal that the intensity of deformation in the interior of the granite body is different from its margin. Outcrops of massive granite in the central part of the Vellaturu body show weak imprints of solid state deformation in the form of local fractures and patches of cataclasites. The border zone, a few tens of metres wide, shows discrete $\mathrm{cm}$-scale shear zones anastomosed around low strain domains. The outermost margin of the granite is marked by an approximately $2-3$ metre thick zone of strongly foliated granite mylonite with S-C fabric (figure 5D). Apart from strong flattening and grain size reduction, the $\mathrm{S}-\mathrm{C}$ fabric suggests upward displacement of the granite interior relative to its margin at the level of present exposure. S-C fabric along with stretching lineation has been observed from southern margin (sample location $25 \mathrm{~d} 697$ ) where the mylonitic foliation dips 50-60 toward south (or SSE) and the stretching lineation is nearly downdip. Near Koppu Konda, the foliation dips $60-70^{\circ}$ toward $\mathrm{W}(\mathrm{WNW})$ and S-C relationship indicates top-to- $\mathrm{W}$ displacement along the margin. In the northeastern part of the Vellaturu granite around Agnigundla, mylonitic foliation dips 40-45 toward E (or ENE) and the stretching lineation plunges $20-30^{\circ}$ toward E (or ESE). East of Bollapalle the magmatic foliation in the granite shows change in orientation within a short distance (figure $3 \mathrm{~A}$ ) and subsolidus deformation overprint leads to S-C fabric close to the northern margin of the granite.

\section{Microstructure and texture}

\subsection{Weakly-deformed granite}

Thin sections of weakly-deformed granite are marked by porphyroclasts of plagioclase (albiteoligoclase), microcline and perthites in a matrix of undulose quartz, kinked biotite, muscovite and chlorite. Microfracturing in feldspar is ubiquitous (figure 6A). Tuttle laminae or healed microfractures, deformation bands and subgrains are common in quartz (figure 6B), but chessboard subgrain pattern (Kruhl 1996) is absent. In domains of discrete shear zones, quartz ribbons show minor bulging recrystallization along ribbon boundaries or at microfracture sites. Occasional development of kinks and tapering twin lamellae (deformation twins) in plagioclase (figure 6C) indicate limited plastic deformation of feldspar. Brown biotite flakes show undulose extinction, sometimes with exsolved rutile needles.

Retrograde changes in weakly-deformed granite include alteration of feldspar to muscovite, chlorite and calcite. Occasional garnets are replaced by biotite preferentially along microfractures and along the margin of the host grain (figure 6D). 

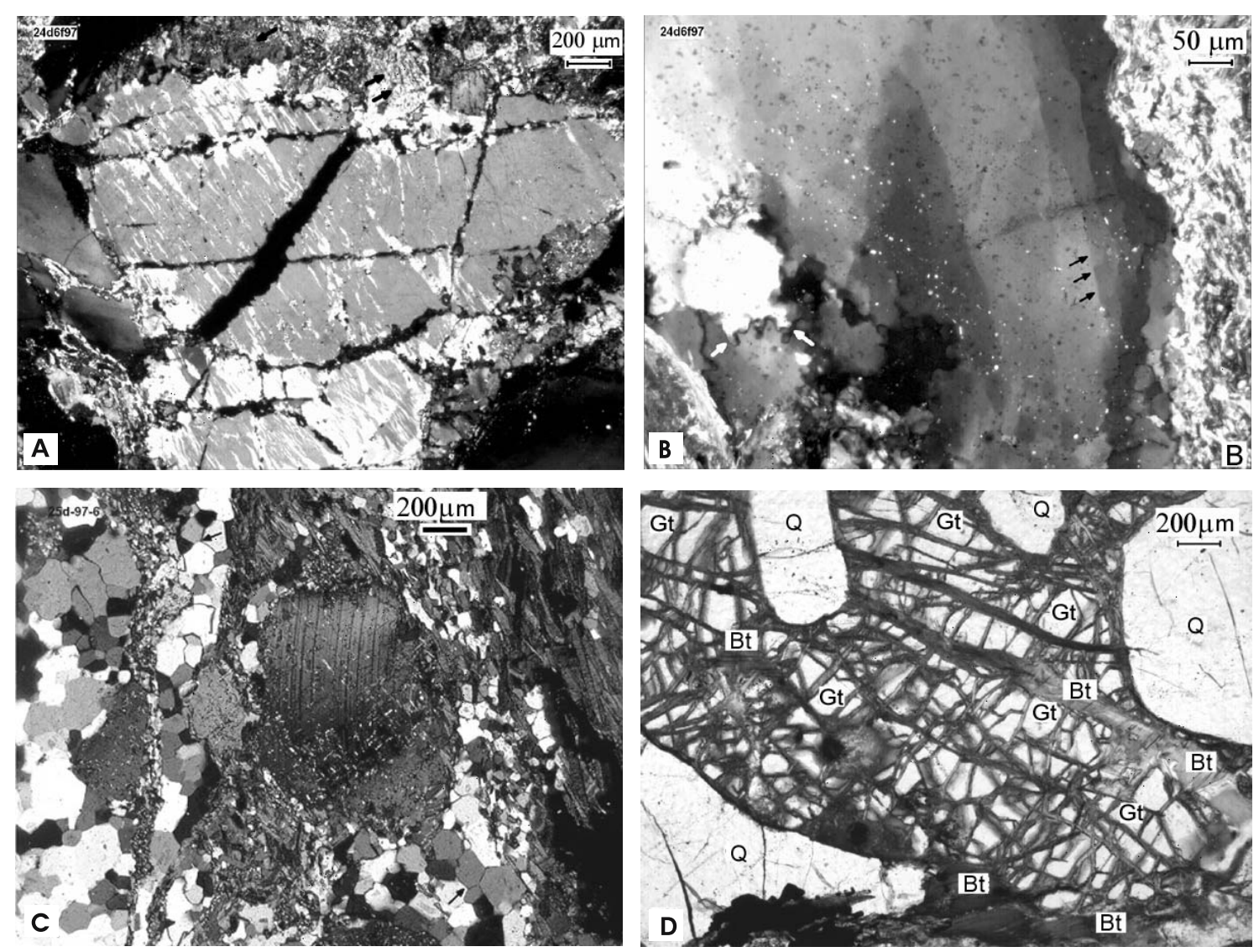

Figure 6. Microstructure in the Vellaturu granite. (A) Microfractures in perthite porphyroclast; sample 24d6f97. Upper margin of the clast has myrmekitic intergrowth (arrow). (B) Prism subgrain boundary (black arrow) and bulging recrystallization (white arrow), sample 24d297. (C) Bent twin lamellae in plagioclase. (D) Biotite (Bt) replacing garnet (Gt) along intragranular fractures. $Q=$ quartz.

Table 1. Size and proportion of recrystallized quartz grains in the Vellaturu granite samples.

\begin{tabular}{ccc}
\hline Sample no. & $\begin{array}{c}\text { Grain size } \\
\text { (equivalent } \\
\text { diameter in } \mu \mathrm{m})\end{array}$ & $\begin{array}{c}\text { Proportion of } \\
\text { recrystallized } \\
\text { grains (\%) }\end{array}$ \\
\hline 31d 897 & $28.10 \pm 19.94$ & 0.98 \\
$24 \mathrm{~d} 197$ & $28.33 \pm 14.45$ & 8.87 \\
$24 \mathrm{~d} 6 \mathrm{f} 97$ & $14.91 \pm 6.97$ & 12.95 \\
$24 \mathrm{~d} 297$ & $23.90 \pm 10.09$ & 20.62 \\
$29 \mathrm{~d} 1 \mathrm{a} 97$ & $43.25 \pm 36.64$ & 80.80 \\
$25 \mathrm{~d} 697$ & $107.60 \pm 51.60$ & 100.00 \\
\hline
\end{tabular}

\subsection{Granite mylonites}

Granite mylonites restricted to a $2-3 \mathrm{~m}$ thick zone in the outer part of the Vellaturu granite are marked by grain size reduction as well as an increase in the proportion of phyllosilicates relative to quartz and feldspar. Both feldspar porphyroclasts and recrystallized quartz ribbons have larger aspect ratios compared to those in the weaklydeformed granite representing the pluton interior. While the weakly-deformed granites have 1-20 volume per cent of dynamically recrystallized quartz, well-foliated mylonites with composite S-C fabric have almost completely recrystallized quartz (80-100\%; sample 29d1a97 and 25d697 in table 1; figure 7A). Recrystallized quartz grains (size $28 \pm 14 \mu \mathrm{m}$, sample 24d197) in weakly-deformed granite have low amplitude grain boundary lobes as in low- $\mathrm{T}$ bulging recrystallization. In totally recrystallized quartz ribbons, the recrystallized grains are relatively larger (size $\sim 108 \pm 51 \mu \mathrm{m}$, granite mylonite sample 25d697) with straight to gently curved grain boundaries. The matrix contains recrystallized feldspar, quartz, biotite and muscovite with a strong alignment of phyllosilicate (001) planes. Foliated granite mylonites show a strong kinking and recrystallization of biotite. Biotite-fish and biotite flakes defining individual folia are locally cut by $\mathrm{C}$-shears in $\mathrm{XZ}$ section (figure 7B). S-C relationship (figure 5D) indicates relatively upward displacement of the northern block relative to the southern block where the mylonitic foliation dips steeply towards south along the southern margin of the granite body. The corresponding stretching lineation has $40-45^{\circ}$ plunge towards south. Pervasive grain scale S-C fabric in the fine grained mica rich mylonites follow 

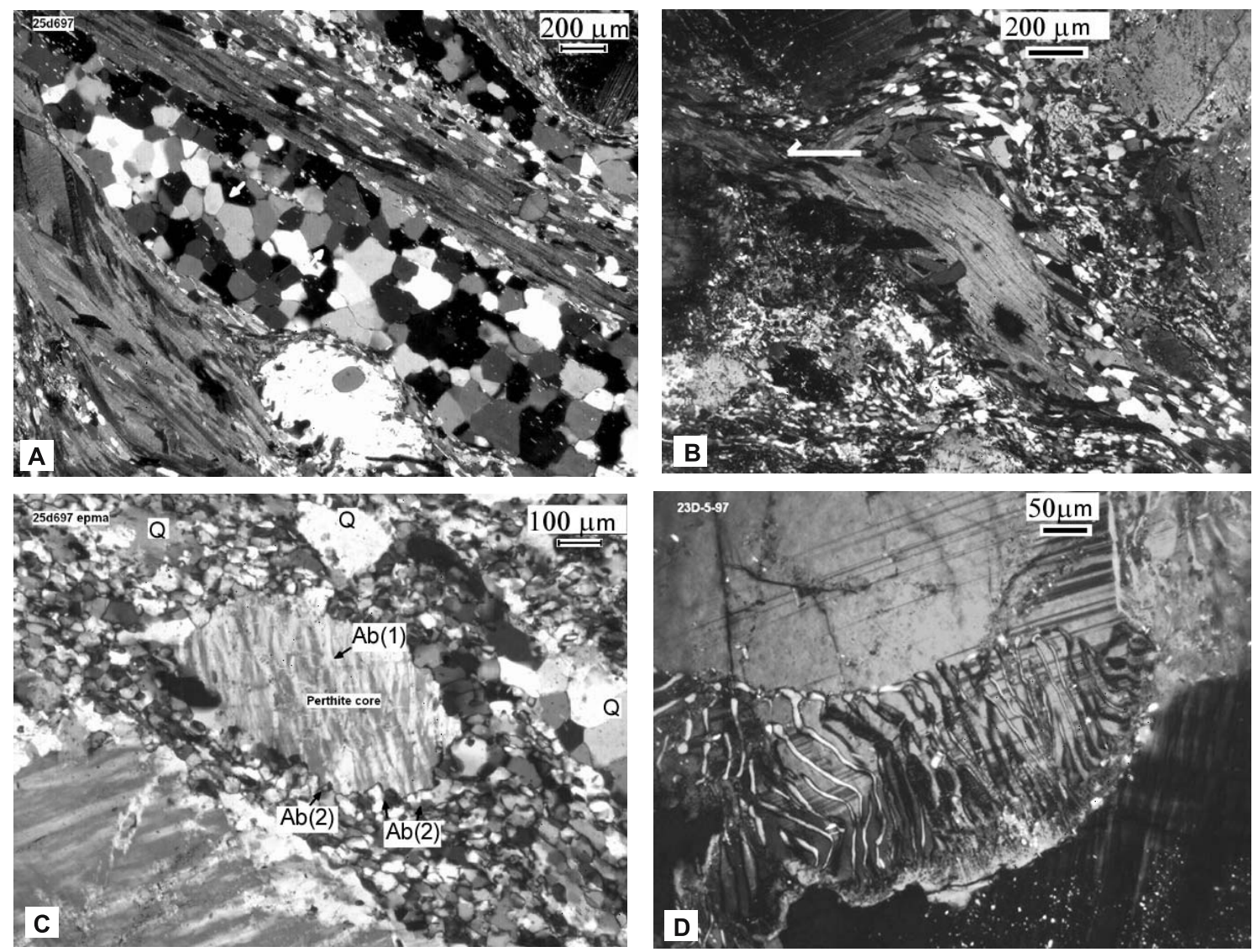

Figure 7. (A) Recrystallized quartz ribbon in granite mylonite; sample 25d697. Note straight boundary and triple junction (white arrow). (B) Biotite fish in granite mylonite; sample 25d697. Single barb arrow to indicate C shears. Thin section perpendicular to mylonitic foliation and parallel to stretching lineation. Sense of shear top-to-S along $\mathrm{C}$ shears dipping $60^{\circ}$ toward south. (C) Perthite with core and mantle structure. Ab(2) for recrystallized albite grains; sample 25d697. (D) Lobe of myrmekite at the contact between plagioclase and microcline (bottom right). Note bent quartz tubule and tapering albite twins; sample $23 \mathrm{~d} 597$.

the same geometry as in macroscopic fabric in the thin mylonitic outer margin of the granite body.

Microcline and perthite porphyroclasts show microboudins and occasionally book-shelf structure. Kinks, subgrains and core-and-mantle structure are also observed in some perthites (figure 7C). Deformation twins as well as bent twin lamellae are common in plagioclase porphyroclasts.

In the deformed Vellaturu granite, myrmekite is quite common and occurs in both, weaklydeformed granites as well as in granite mylonites. Myrmekitic lobes are seen to invade the margin of K-feldspar grains with bent quartz tubules in the intergrowth (figure 7D). Host plagioclase in these lobes (usually albite or sodic oligoclase) show tapering albite-twins, some of which are themselves bent. In addition, in the strongly foliated granite mylonite, the lobes are preferentially placed along feldspar margins subparallel to the overall foliation indicating influence of deformation in myrmekite generation (Simpson and Wintsch 1989).

\subsection{Quartz c-axis fabric}

In the granite mylonites, the quartz ribbons are thoroughly recrystallized (100\% in $25 \mathrm{~d} 697$ ) with straight to gently curved boundaries of recrystallized quartz grains. The recrystallized grains form high angle boundaries including some triple junctions (figure $7 \mathrm{~A}$ ). The grain size in the granite mylonites is relatively larger compared to those in weakly-deformed granite with some showing limited bulging recrystallization of quartz ribbon boundaries. Quartz c-axis orientations in recrystallized grains in granite mylonite samples were measured using a universal stage fitted to a CZ Zenapol optical microscope and plotted with respect to mylonitic foliation-stretching lineation reference frame.

Lower hemisphere equal-area plot of $c$-axis orientations in sample 25d697 from the southern margin of the Vellaturu granite body shows well-defined Y-maximum. A skeletal girdle, containing the Ymaximum, a peripheral maximum and sub-maxima 


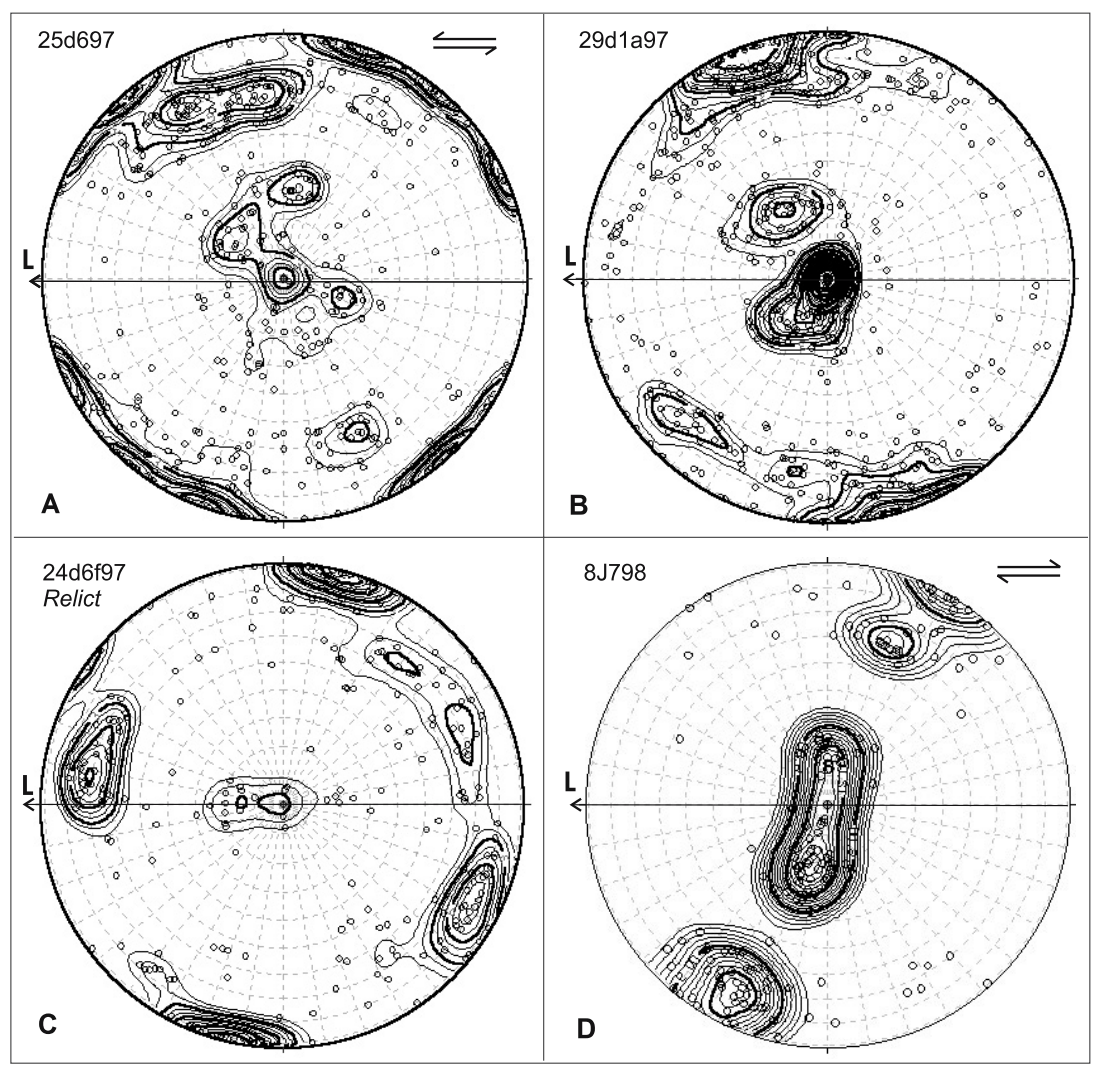

Figure 8. Quartz $c$-axis fabric in recrystallized quartz ribbons in granite mylonites. Lower hemisphere equal area plot, foliation trace along $\mathrm{E}-\mathrm{W}$ and top of foliation is toward upper half of the plots. Contour interval $1 \sigma ; 3 \sigma=\mathrm{E}$, expected value for uniform distribution. (A) Sample 25d697 from southern margin where mylonitic foliation dips towards south stretching lineation plunges $50^{\circ}$ towards SSE. Note strong Y-maximum (centre) and obliquity of girdle through Y. Fabric asymmetry indicates a strong component of top-to-left shear. (B) Sample 29d1a97 from northeastern part where foliation dip is $40^{\circ}$ towards ENE and stretching lineation plunges $20^{\circ}$ towards east. Main girdle through $\mathrm{Y}$ and sense of shear as in 25d697; note vestiges of a cross girdle and a second set of peripheral maximum. (C) c-axis fabric in relict quartz porphyroclasts in weakly-deformed sample 24d6f97; L represents mineral elongation lineation; details in text. (D) $c$-axis fabric in dynamically recrystallized quartz grains, quartz mylonite sample from the eastern margin of the NFB and away from the granite margin. Strong asymmetric girdle pattern through Y. Stretching lineation (L) plunges $23^{\circ}$ towards ESE and the fabric asymmetry indicates a sense of shear opposite to that in granite mylonite samples.

at intermediate orientations, occurs at a high angle to foliation (figure 8A). The trace of mylonitic foliation is plotted along $\mathrm{E}-\mathrm{W}$ with upper side of foliation towards north and plunge direction of lineation towards left $(\mathrm{W})$ on the periphery of the plot. Here, Y direction of the finite strain ellipsoid is considered to be perpendicular to the stretching lineation on foliation. In the geographic reference frame, the local mylonitic foliation dips $40-50^{\circ}$ towards south near the contact with the country rock. The stretching lineation plunges towards south. The fabric asymmetry, defined by obliquity $\left(\sim 20^{\circ}\right)$ of the skeletal girdle from the foliation normal, indicates a left-handed component of shear as seen on the plot and consistent with the upward displacement of the granite mass relative to the outer margin. Mismatch in $c$-axis orientations between neighbouring grains in recrystallized ribbons for 25d697 are shown in figure 9. A significant proportion of the recrystallized grains have mismatch angles $\leq 20^{\circ}$ indicating subgrain rotation and polygonization (cf. regime II recrystallization of Hirth and Tullis 1992). However larger mismatches are also common.

Sample 29d1a97 from the northeastern margin of the Vellaturu body has a skeletal girdle with maxima and asymmetry similar to those of $25 \mathrm{~d} 697$. But vestiges of a cross girdle with peripheral maximum are also apparent (figure 8B). The local foliation dips $40^{\circ}$ eastward. In addition, a sample of a weakly-deformed but foliated granite (24d6f97) from a location about $50 \mathrm{~m}$ east of the western margin around Koppu Konda was measured for $c$-axis orientation in the relict quartz porphyroclasts for comparison with fabric in samples with almost complete recrystallization. Sample 24d6f97 has only about $13 \%$ recrystallized quartz. The fabric shows multiple peripheral maxima close to mineral elongation lineation as well as foliation normal but little Y-concentration (figure $8 \mathrm{C}$ ). 
The development of Y-maximum fabric is evidently related to dynamic recrystallization due to mylonitization along the margin of the Vellaturu granite.

The quartz $c$-axis fabric in quartz mylonites along the footwall of the major boundary thrust at the eastern margin of the NFB also shows an asymmetric girdle pattern with respect to the southeasterly dipping mylonitic foliation and stretching lineation which plunges at $20-30^{\circ}$ towards southeast. Peripheral maximum at a high angle to $\mathrm{X}$ (stretching lineation) as well as $\mathrm{Y}$ maximum are present (figure 10D). However, the sense of asymmetry is indicative of top-to-NW relative displacement of the hanging wall (i.e., Nellore schist belt rocks east of the major boundary thrust). The quartz mylonite with oblique grain shaped fabric and strong $c$-axis fabric in the Nallamalai quartzites occurring about $2 \mathrm{~km}$ east of the Vellaturu granite margin, however, represents earlier $\left(D_{1}\right)$ deformation (Saha 2002).

\subsection{Quartz subgrain boundaries}

Activation of slip systems during plastic deformation of quartz is strongly temperature dependent (e.g., Christie et al 1964; Baeta and Ashby 1969; Hobbs et al 1972; Blacic 1975; Kruhl 1996). It is generally accepted that while basal $\langle a\rangle$ slip is the dominant slip system under low-temperature plastic deformation of quartz, prism $\langle c\rangle$ slip occurs under elevated temperature $\left(600^{\circ} \mathrm{C}\right.$ and above, granulite facies). On the other hand, for lowtemperature grain scale homogeneous deformation activation of other slip systems, namely prism $\langle a\rangle$ and rhomb $\langle a\rangle$ are necessary and reported from both naturally occurring plastically deformed quartz aggregates and experimental deformation of quartz (e.g., Trepmann and Stöckhert 2003; Gleason et al 1993). Straight subgrain boundaries (sgb) and deformation lamellae are important optical microstructures in the interpretation of relative activity of slip systems in quartz. Basal to subbasal deformation lamellae and prism sgb are usually associated with low-temperature $\left(300-350^{\circ} \mathrm{C}\right)$ deformation (e.g., Kruhl 1996). Basal to subbasal sgb on the other hand represents deformation under higher temperature. The occurrence of chessboard subgrain pattern in quartz indicating simultaneous activation of basal and prism slips is considered to be an important indicator of high-temperature subsolidus deformation (Kruhl 1996).

Partially recrystallized quartz ribbons from the Vellaturu granite samples show profuse development of prism subgrains (figure 10). Irregular subgrain boundaries are also not uncommon. Elongate subgrains and deformation bands are also

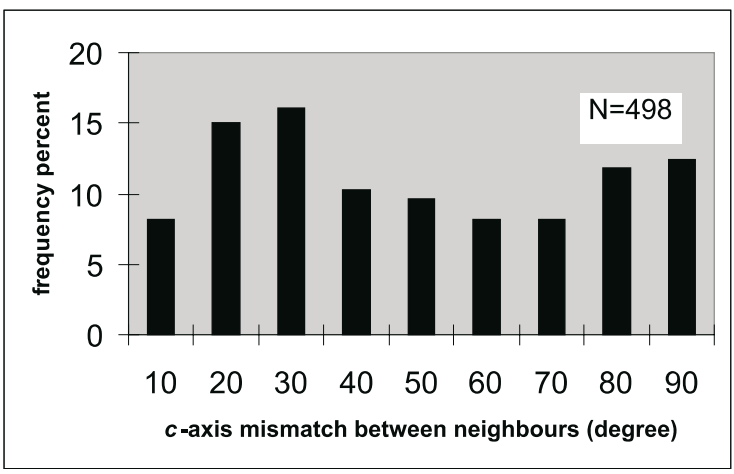

Figure 9. Mismatch in $c$-axis orientations of neighbours in recrystallized quartz ribbons; sample $25 \mathrm{~d} 697$.
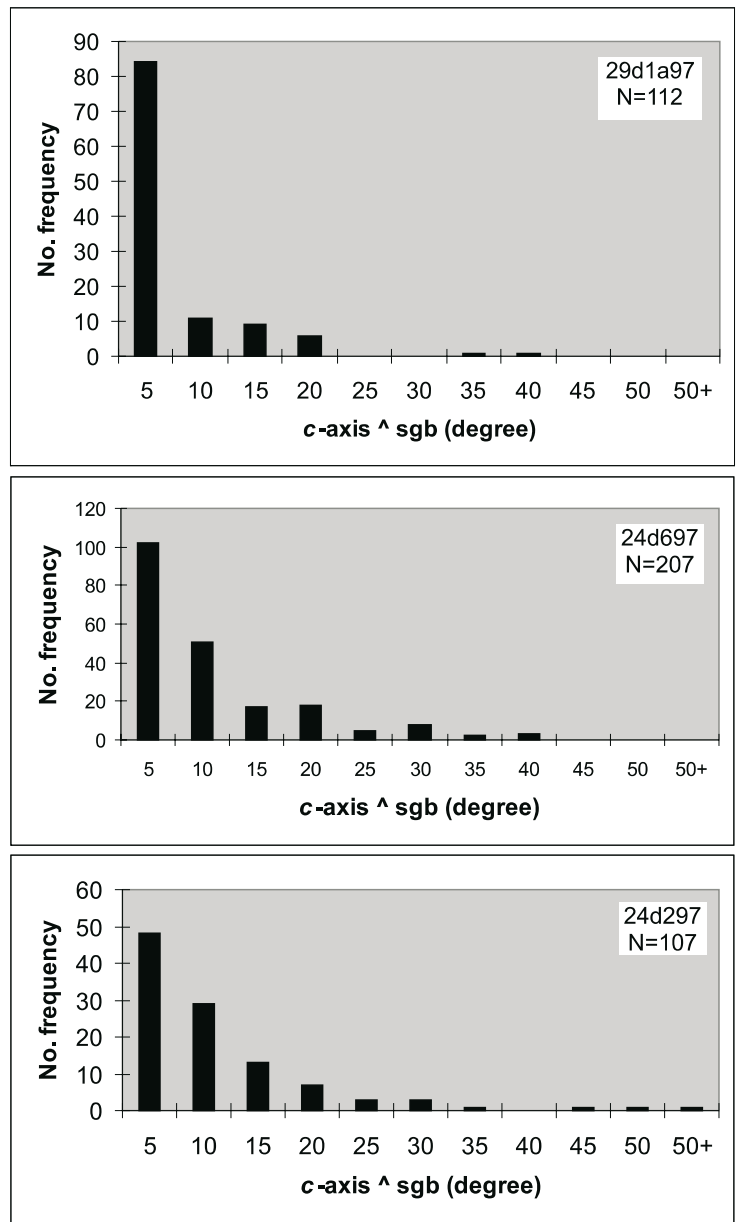

Figure 10. Orientation of quartz subgrain boundary (sgb). Angle between individual quartz $c$-axis azimuth and trace of subgrain boundary measured on a plane roughly perpendicular to sgb and containing the $c$-axis. Abundant prism sgb is indicated by largest frequency in the $\leq 5^{\circ}$ class for all the measured samples.

accompanied by sub-basal deformation lamellae. But chessboard subgrain pattern is typically absent in granite samples from weakly-deformed interior or the strongly deformed mylonitic samples at the margin of the Vellaturu granite. 


\section{Discussion}

\subsection{Quartz microstructure, recovery and recrystallization}

The crystallographic fabric and microstructure resulting from dynamic recrystallization and recovery in quartz are considered proxy indicators of ambient temperature (and strain rate) in deformed quartz aggregates. Three processes, namely grain boundary migration recrystallization (gbm) and grain boundary rotation recrystallization and bulging recrystallization are generally thought to represent recovery and recrystallization at successively lower temperatures subject to strain rate variation (Hirth and Tullis 1992; Stipp et al 2002).

Bulging recrystallization, dominated by local grain boundary migration, leads to small grain boundary lobes (Vernon 2000) and small recrystallized grain size (5-25 $\mu \mathrm{m}$, Stipp et al 2002). Low amplitude bulges and recrystallized grains are present mainly along older grain boundaries. Progressive subgrain rotation leads to polygonization of older grains and formation of newly recrystallized grains of size comparable to the subgrains. Rotation recrystallization is indicative of intermediate temperatures as exemplified by textures in quartz aggregates deformed at the higher-temperature end of the greenschist facies or lower amphibolite facies. Fast gbm recrystallization assisted by combined dislocation climb and diffusion commonly leads to large recrystallized grain size $(200-300 \mu \mathrm{m}$ and above; regime III of Hirth and Tullis 1992). High T grain boundary migration recrystallization (say under granulite facies) leads to irregular grain shapes and sizes and a wide variation in grain size (Stipp et al 2002). Straight grain boundaries and triple junctions indicate annealing.

Based on the above general criteria, the observed subsolidus microstructures from the Vellaturu granite are interpreted in terms of ambient deformation temperature. The latter may be indirectly translated to the level of emplacement and orogenic imprint. The heat released from the cooling granite also influences the development of microstructures in the granite body and its aureole. Distinctly smaller size of recrystallized quartz grains (1528 micron) with low amplitude sutured ribbon boundaries in the weakly-deformed samples (e.g., 24d197, 24d6f97; table 1, figure 6) of the Vellaturu granite are indicative of solid state deformation under low-to-medium greenschist facies condition. On the other hand, the completely recrystallized quartz ribbons with straight grain boundaries, triple junctions and relatively larger recrystallized grain size $(\sim 108 \pm 51 \mu \mathrm{m}$; sample $25 \mathrm{~d} 697)$ indicate influence of rotation recrystallization process and perhaps some degree of static grain growth by grain boundary area reduction. Thus the quartz microstructure of the Vellaturu granite mylonites is consistent with deformation under low amphibolite facies to upper greenschist facies condition (400-500 ${ }^{\circ}$; Simpson 1985; Stipp et al 2002).

\subsection{Quartz c-axis fabric and ambient temperature of deformation}

The simulated quartz $c$-axis patterns for different combinations of slip systems reflecting different temperature regimes is now fairly well known (e.g., Etchecopar 1977; Lister et al 1978; Jessell and Lister 1990). Natural fabrics from quartzrich rocks with independent control on ambient deformation temperature suggest that the $c$-axis fabric pattern often reflects relative influence of different slip systems in quartz (Schmid and Casey 1986; Kruhl 1996). It is generally agreed that dominance of basal $\langle a\rangle$ slip system which is the easiest one in quartz leads to a peripheral caxis maxima close to finite Z-axis under relatively low-temperature deformation. On the other hand, Y-maximum fabric is generally interpreted as indicative of significant prism $\langle a\rangle$ slip activated under elevated temperature, say that of amphibolite facies (Mainprice et al 1986). (X $>\mathrm{Y}>\mathrm{Z}$ ) represent axes of finite strain. An orthorhombic fabric reflects pure shear type deformation whereas a monoclinic fabric is indicative of significant simple shear component (Lister and Hobbs 1980). Thus the quartz $c$-axis fabric pattern in natural tectonites may be used as broad qualitative indicator of ambient temperature (Nicolas and Poirier 1976; Stipp et al 2002).

In the measured samples $(25 \mathrm{~d} 697,29 \mathrm{~d} 1 \mathrm{a} 97)$ of mylonitized Vellaturu granite, there is a strong Y-maximum for recrystallized quartz, lying on a skeletal girdle at a high angle to the mylonitic foliation and lineation (figure 8). The Y-maximum is also in strong contrast to the $c$-axis fabric obtained from relict grains in weakly-deformed sample 24d6f97. Dynamic recrystallization of quartz and fabric development under low amphibolite facies is indicated as the Vellaturu granite was emplaced in the upper crust. The fabric asymmetry suggests influence of non-coaxial deformation. The sense of asymmetry obtained from sample 25d697 and 29d1a97 are consistent with relative upward displacement of the Vellaturu granite interior relative to the margin. Subsequent low-temperature deformation at shallow level is reflected in brittle microfractures in feldspar, bulging recrystallization in quartz and possibly peripheral quartz $c$-axis maxima at a high angle to foliation. The abundance of prism subgrain boundary is also indicative of low-temperature crystal plasticity in quartz. 
The fabric evolution continued till the granite body cooled to the ambient temperature of greenschist facies country rocks during the late phase $\left(D_{3}\right)$ of regional deformation.

\subsection{The lack of preservation of high temperature subsolidus microstructures}

The absence of high- $\mathrm{T}$ subsolidus deformation microstructure in quartz in the Vellaturu granite may be interpreted either as non-development due to faster cooling rate compared to strain rate, as elaborated below, or due to complete obliteration of the early formed high- $\mathrm{T}$ microstructures and fabric during later intense low- $T$ deformation. As described earlier, the deformation of the Vellaturu granite was influenced by strain partitioning, the major subsolidus strain accumulation and mylonite development being focused in the outer margin. The interior was relatively protected particularly after the development of a mylontic skin, but a weak solid state deformation is perceptible at many interior localities. Since subsolidus deformation imprint and consequent microstructure and fabric development is more intense in the thin outer margin of the granite, the high- $\mathrm{T}$ microstructures are more likely to be obliterated in this domain than in the weakly-deformed interior. Had there been common development of high-T subsolidus microstructure like chessboard subgrain pattern in quartz, these structures would have been preserved in the weakly-deformed domains of the granite. Although the interior of the granite is weaklydeformed, both medium and low- $\mathrm{T}$ deformation microstructures are present in the Vellaturu granite (e.g., samples 24d197, 24d297, 31d897; figure 6). As the proportion of recrystallized quartz grains is relatively low $(<20 \%)$ and quartz ribbons with low amplitude sutured boundaries are still preserved, it is highly unlikely that the early formed high$\mathrm{T}$ microstructures would be completely lost had they formed in the first instance. Thus we favour the alternative hypothesis of non-development of high-T quartz microstructures in the Vellaturu granite.

\subsection{Primary magmatic fabric versus secondary tectonic fabric}

Magmatic foliation and lineation in granite may originate from internally driven processes such as buoyancy and rheological differences between magma surges, and/or due to the influence of regional strain within a magma chamber still retaining some melt fraction (Clemens 1998; Paterson et al 1998). Planar to linear fabric arises from alignment of mineral grains (or clots of grains) of platy, tabular or acicular habit and retaining euhedral to subhedral shape, and crystallized from a melt. Feldspars, both plagioclase and alkali feldspars, and biotite and hornblende may show shape preferred orientation leading to various types of L-S fabric. In a pristine magmatic fabric the constituent grains are usually strain free and are likely to retain their euhedral to subhedral form. Such fabric in cooling igneous bodies are thought to represent late stage developments when the melt proportion is less than $25 \%$ and the fabric development is also known to be influenced by regional strain (Paterson et al 1998). Solid state deformation of the emplaced granite attested by subsolidus deformation microstructure may lead to enhancement of the original fabric and/or overprinting by a newly acquired secondary fabric (Blumenfeld and Bouchez 1988; Vernon 2000). As described earlier remnant magmatic foliation is common in the porphyritic variety of the Vellaturu granite, where alignment of subhedral feldspar phenocrysts define the foliation. Similarly alignment of biotite clusters in weakly-deformed gray granites locally defines the foliation. Additionaly the presence of schlieren in the vicinity of metasedimentary enclaves around Koppu Konda and Barra Konda represent magmatic flow recording strong velocity gradient near the interface between the stoped block and surrounding magma. The orientations of the remnant magmatic foliation in the Vellaturu granite do not follow the regional tectonic trend and is difficult to reconcile with the regional strain field responsible for NE-SW trending $\mathrm{F}_{2}$ domal structure and crenulation cleavage in the host rock (Saha 2002). Late stage internal adjustments in the crystal mush within the magma chamber may have led to internally complex fabric pattern in the Vellaturu granite, which point toward rheological decoupling between the near solidified Vellaturu granite and the surrounding Nallamalai rocks, during the late phase $\left(\mathrm{D}_{3}\right)$ of regional deformation. Protomylonitic to mylonitic foliation representing solid state overprint on the magmatic fabric is more common along the margin of the granite (figure 3). Development of Y-maximum quartz $c$-axis fabric is also noted in samples from the marginal zone of granite mylonites.

\subsection{Relative rates of cooling and deformation}

One of the strongest single criteria for recognizing syntectonic plutons is thought to be the presence of a gradation of fabric indicative of magmatic, i.e., beyond RCMP threshold, through hightemperature solid state deformation in granites and other plutons (e.g., Paterson et al 1989; Miller and Paterson 1994). Such transition in textures has been well documented from migmatitic terrains 
(e.g., Gapais and Barbarin 1986; Blumenfeld and Bouchez 1988) and in batholiths (e.g., Miller and Paterson 1994; Pawley and Collins 2002). However, any lack of continuum of down temperature fabrics in otherwise well established syntectonic plutons may result from relatively slow strain rate compared to pluton cooling rates (Paterson and Tobisch 1992; Miller and Paterson 1994; Tribe and D'Lemos 1996; Pitcher 1997). In the case of Vellaturu granite, although alignment of subhedral feldspar crystals and schlieren associated with metasedimentary enclaves indicate remnant magmatic fabric, high-temperature solid state deformation fabric is absent from the constituent minerals. As agrued earlier, we rule out the possibility of complete obliteration of an early formed quartz microstructure and quartz $c$-axis fabric during low- $T$ deformation because even in samples with realtively low crystal plastic strain and low degree of quartz recrystallization, high-T quartz microstructures like chess-board microstructure in quartz (Kruhl 1996) or subgrain boundaries of basal or sub-basal orientation are missing in the Vellaturu granite.

On the other hand, intermediate-temperature $\left(400-500^{\circ} \mathrm{C}\right)$ deformation texture, such as coreand-mantle structure in partially recrystallized alkali feldspar (figure 6), Y-maximum quartz $c$-axis fabric in completely recrystallized quartz ribbons (figure 8) are well preserved in granite mylonites along the thin contact zone with the wall rock. Subgrain rotation recrystallization (Regime II of Hirth and Tullis 1992) indicated by small mismatch between neighbours in significant proportion of recrystallized grains (figure 9) suggests slow cooling through intermediate temperature window. The influence of deformation in the generation of myrmekites and their preferential development under amphibolite facies condition has been advocated by Simpson (1985) and Simpson and Wintsch (1989) (cf. Cesare et al 2002). Comparable abundance of myrmekites in the granite mylonites and weakly-deformed granites from the central part of the Vellaturu granite suggests accumulation of some strain increments across the granite body during solid state plastic deformation as the granite cooled through the intermediate temperature window.

Weakly-deformed granite samples (e.g. 24d6f97), however, contain abundant bulging recrystallization with relatively small proportion of recrystallized quartz (1-20\%) and small size $(15-28 \mu \mathrm{m}$, table 1). Brittle microcracking and cataclasis of feldspars and quartz are also present in the weakly-deformed samples. These microstructures imply low temperature deformation (Hirth and Tullis 1992; Stipp et al 2002). The granite mylonite samples also contain late stage retrograde overprints as indicated by kinks and undulose extinction in chlorites aligned subparallel to the mica folia in composite $\mathrm{S}-\mathrm{C}$ fabric. However, the higher intensity of plastic strain in the contact zone mylonites apparently accumulated under intermediate- to low-temperature condition and preferential preservation of low-temperature deformation microstructures in the weakly deformed central part of the Vellaturu granite body necessitates some explanation.

Assuming the solidus for wet granites to be around $650-750^{\circ} \mathrm{C}$ (Yardley 1989; Pitcher 1997), one may suggest that the Vellaturu granite after its emplacement in the upper crust and in the early subsolidus stage cooled relatively rapidly so as to escape any significant high-temperature plastic strain. For a cooling intrusive body the conduction of heat through its own body and the wall rock is affected mainly by relative proportion of mineral phases and their distribution as the primary porosity is generally low in igneous rocks (Clauser and Huenges 1995). However, the granite was subjected to regional $\mathrm{D}_{3}$ strain affecting the Nallamalai Group of metasediments showing lower greenschist mineral assemblage as well as emplacement related strain. One may recall here that kinematic interpretation of fabric and microstructures from the Vellaturu granite mylonites consistently favours relative upward displacement of the interior of granite body relative to its outer margin with steep outward dipping foliation.

Formation of granite mylonites under epidoteamphibolite to greenschist facies is accompanied by a strong grain size reduction and increase in the proportion of phyllosiliocates (muscovite and biotite) at the expense of feldspar through mediation of aqueous fluids (e.g., Wintsch et al 1995; Hippertt 1998; Wibberley 1999). A strong composite S-C fabric also imparts a thermal anisotropy in the mylonitic contact zone. Thermal conductivity measurement for rocks and minerals provides a first approximation of the thermal parameters which influence the natural cooling of the crust or any upper crustal pluton. However, conductivity of quartz and hence quartzite is usually higher compared to feldspar, phyllosilicates such as biotite, chlorite and muscovite, and mafic minerals like epidote and hormblende and granitic rocks (Clark 1966; Clauser and Huenges 1995; table 2). As the immediate wall rock surrounding the Vellaturu granite body consists dominantly of quartzite (Saha 2002), it is likely that conductive heat loss from the Vellaturu body through host metasediments was uniform across the body and relatively fast. However, the development of a mylonitic skin around the granite body, partially slowed down the conductive heat loss as higher proportion of mica, and anisotropy resulting from 
Table 2. Conductivity of common rock forming minerals (after Clauser and Huenges 1995).

\begin{tabular}{lc}
\hline Mineral/rock & $\begin{array}{c}\text { Conductivty } \lambda \\
\left(\mathrm{W}^{-1} \mathrm{~m}^{-1} \mathrm{~K}^{-1}\right)\end{array}$ \\
\hline Hornblende & $2.91 \pm 0.09$ \\
Muscovite & $3.89(1), 0.62 \pm 0.11(2)$ \\
Biotite & $3.14(1), 0.52 \pm 0.01(2)$ \\
Chlorite & $3.06 \pm 1.18$ \\
Orthoclase & $2.30 \pm 0.21$ \\
Quartz & $10.17(1), 6.15(2)$ \\
Quartzite & $5.8 \pm 0.4$ \\
Plutonic rocks & $2.6 \pm 0.4$ \\
rich in feldspar & \\
\hline
\end{tabular}

(1) Along direction of maximum $\lambda$; (2) Along normal to (1); others unspecified; values for temperature at $\sim 300 \mathrm{~K}$.

their alignment in interconnected folia led to a dynamic mantle of lower conductivity. The strong rotation recrystallization and apparent foam structure in quartz ribbons in the granite mylonites (e.g., sample 25d697) suggest a slower rate of cooling compared to rate of deformation.

\subsection{Advective heat loss}

Fluid driven heat advection can be important also in crystalline rocks and on a crustal scale (Fyfe et al 1978; Etheridge et al 1983; Torgersen 1990). One of the ways of increasing porosity in granitic rocks and thus facilitating advective heat transfer is through development of transgranular fractures and microcracking of the constituent phases namely feldspar and quartz. At higher temperatures, both feldspar and quartz deform plastically and are likely to preserve deformation microstructures such as chessboard subgrain pattern in quartz and migration recrystallization indicative of higher ambient temperature provided the cooling rate is not too fast.

On the other hand, if the interior of the granite body behaves as an interconnected crystal mush (thus apparently a non-Newtonian viscous or Bingham solid) with the residual liquid facilitating advective heat transfer from the hot interior to the border zone then one can explain faster cooling of the pluton interior particularly through the high-temperature ranges of the subsolidus domain (figure 11). This also explains the apparent absence of high- and intermediatetemperature quartz microstructures and fabric in weakly-deformed granite samples from the interior of the Vellaturu granite. Development of intragranular and/or transgranular cracks under fast strain rate in high temperature regime also facilitate migration of fluids.

At lower temperatures, feldspar is more rigid compared to quartz (Simpson 1985) and the

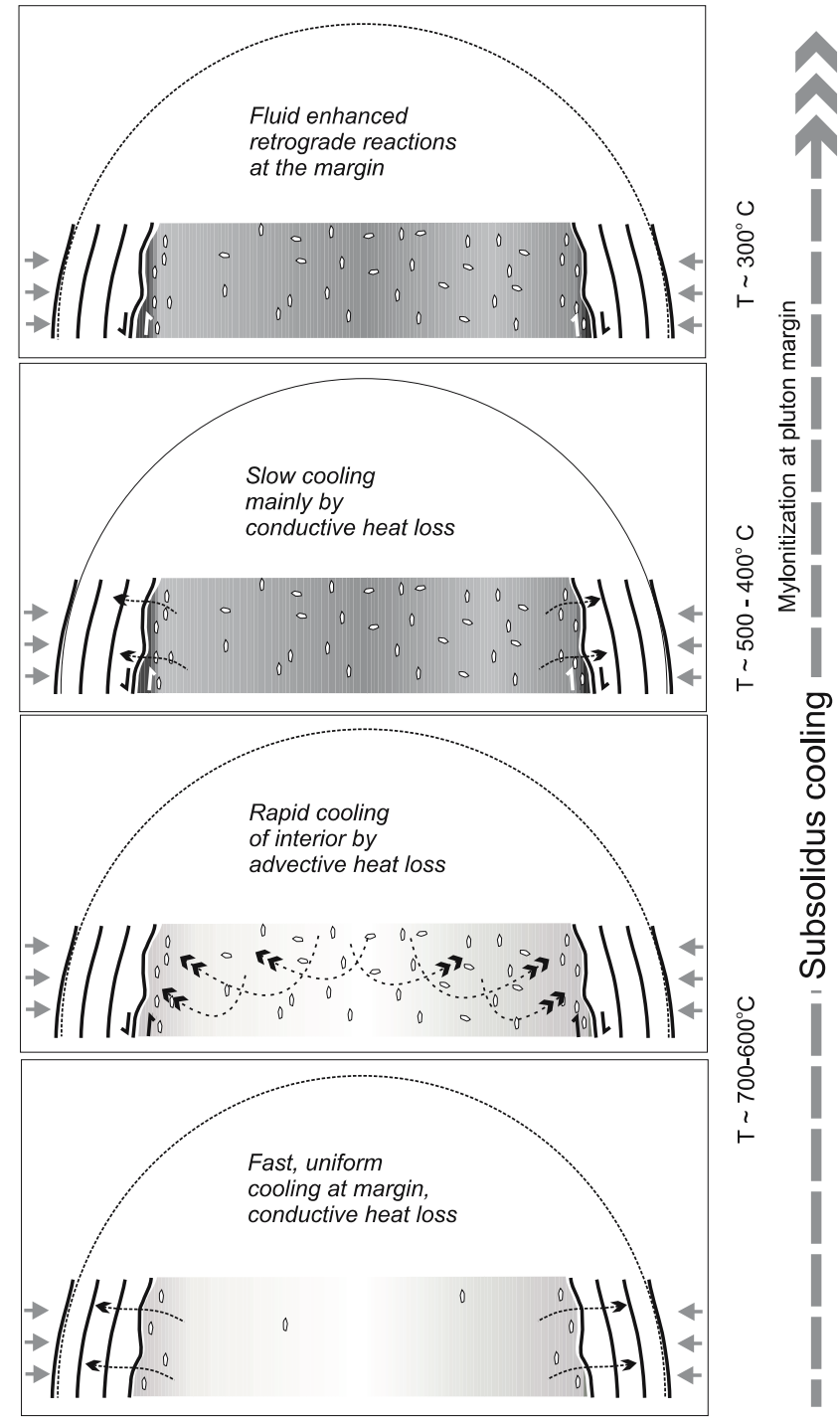

Figure 11. Schematic drawing showing subsolidus cooling history of the Vellaturu granite and the influence of advective heat transfer to the pluton margin.

crystalline aggregate cools relatively slowly by heat conduction. This is inferred to have allowed later increments of strain in the Vellaturu granite to be accommodated by microcracking in feldspar and subgrains with prism subgrain boundary in quartz. Low-temperature recovery led to bulging recrystallization in quartz.

\subsection{Overprinting of magmatic fabric by mylonitization and late-stage reaction softening}

Once a sufficient volume of granitic magma accumulates in the hot lower crust its ascent to shallower levels is driven mainly by bouyancy. Tectonic stresses may play a complimentary role in the ascent particularly by generating upward directed flow and channel ways along weaker zones, such 
as major shear zones and fracture related conduits. In the latter case, as the magma cools and passes through the threshold of rheologically critical melt fraction (Clemens 1998), early magmatic fabric is overprinted by essentially solid state flow. Some magma pulses evidently reached the upper crust ( $\sim 10-15 \mathrm{~km}$ of depth) as indicated by greenschist facies mineral assemblage in the metasedimentary enclave and in the schlieren surrounding them.

The presence of late magmatic fluids influence the emplacement and attendant changes on several counts. The fluids produce reaction softened material and allows the intrusive material (largely solid) to adjust itself to the shallow crustal regional strain. Higher partial pressure of fluids also favours some reactions to proceed in the appropriate direction. For example, the conversion of feldspars to white micas in granites is enhanced by higher partial pressure of $\mathrm{H}_{2} \mathrm{O}$. In the case of the Vellaturu granite advective fluid migration to the border zone is inferred to have facilitated late stage reaction softening of granite mylonites as the body intruded the greenschist facies country rock (figure 11).

\section{Conclusion}

In the case of the Vellaturu granite body, the texture and microstructure show a transition from magmatic fabric through intermediatetemperature (low amphibolite facies) solid state fabric to lower-temperature semibrittle (low greenschist facies) deformation fabric. The relict magmatic fabric is defined by alignment of subhedral feldspar phenocrysts and clusters of biotite flakes in weakly-deformed matrix. Internally complex magmatic fabric pattern is discordant with that in the host rock and demonstrates rheological decoupling between shallow crustal intrusive and surrounding country rocks. Deformation during subsolidus cooling is strongly partitioned in the Vellaturu granite and granite mylonites develop only in the outer skin. Thus absence or poor record of deformation fabric in the interior of shallow crustal plutons should be used with caution in interpreting the time relation between intrusion and regional deformation event.

Intermediate-temperature solid state deformation in the Vellaturu granite is represented by recrystallization of perthitic K-feldspar (figure 7C), diffusion controlled myrmekite formation (figure 7D), and a strong Y-maximum quartz c-axis fabric in granite mylonites (figure 8A). Late stage, solid state deformation under greenschist facies led to replacement of garnet by biotite along microfractures, and bulging recrystallization and abundant prism subgrain boundaries in quartz (figure 10).
The quartz $c$-axis fabric evolution under lowtemperature crystal plastic regime continued till the pluton temperature equilibrated with regional greenschist grade metamorphism in the Nallamalai fold belt. The influence of hydrous fluids in the late stage deformation of the granite along its margin is apparent from common feldspar alteration to white mica and mica enriched granite mylonite.

The apparent absence of high-temperature solid state microstructure in the constituent minerals indicates a hiatus in fabric development in the Vellaturu granite, which is syntectonic with respect to regional late phase of deformation $\left(\mathrm{D}_{3}\right)$ in the Proterozoic northern NFB. We suggest that such hiatus in fabric development may be controlled by early, significant advective heat loss from the pluton interior as the intrusive body rapidly cooled through submagmatic high temperature window. Conductive heat loss through the wall of Nallamalai quartzites was fast to start with. However, localization of fluids and strain softening in the border zone led to development of a mylonitic skin in the intrusive Vellaturu granite. Strong anisotropy in the grain-scale $\mathrm{S}-\mathrm{C}$ mylonites and higher proportion of phyllosilicates led to a dynamic mantle of lower conductivity in the contact zone, which facilitated slow cooling rate compared to ambient strain rate as the pluton cooled through intermediate-temperature to greenschist facies temperature. The rate of cooling relative to strain rate thus controls hiatus in fabric development in syntectonic plutons as advocated by Tribe and D'Lemos (1996). But one also needs to consider the advective heat loss and development of a less conductive mylonitic skin to explain the details of hiatus in fabric development in shallow crustal felsic plutons as in the Vellaturu example.

Variation in the cooling rate of intrusive plutons from the submagmatic stage through the subsolidus stage is primarily dependent on thermal gradient. However, advective heat transfer and progressive mineralogical changes particularly in the strongly deformed border zone and anisotropy in heat conduction may significantly influence the cooling history and fabric development in syntectonic plutons.

\section{Acknowledgements}

This contribution is the result of a project on Tectonic Evolution of the Nallamalai Fold Belt sponsored by the Indian Statistical Institute. Field assistance from S N Das and K Orao is thankfully acknowledged. Discussion with C Dobmeier has helped to crystallize some ideas and he is thankfully acknowledged. Dr. Scott R Paterson and an anonymous reviewer are thankfully acknowledged 
for their constructive reviews and many helpful comments on an earlier version of the manuscript.

\section{References}

Baeta R D and Ashby K H G 1969 Slip systems in quartz: I. experiments; Amer. Mineral. 54 1551-1573.

Blacic J D 1975 Plastic deformation mechanisms in quartz: the effect of water; Tectonophys. 27 271-294.

Blumenfeld P and Bouchez J-L 1988 Shear criteria in granite and migmatite deformed in magmatic and solid states; J. Struct. Geol. 10 361-372.

Cesare B, Marchesi C and Connoly J A D 2002 Growth of myrmekite coronas by contact metamorphism of granitic mylonites in the aureole of Cima di Vila Eastern Alps, Italy; J. Metam. Geol. 20 203-213.

Chakraborty S and Saha D 2005 Tectonic stresses and thinskinned tectonics in a Proterozoic fold-and-thrust belt, read from calcite mylonites in the Cuddapah basin, south India; Proceedings, Proterozoic System of India - Evolution $\&$ Economic Potential (ISM, Dhanbad) p. 7.

Chalapathi Rao N, Miller J A, Gibson S A, Pyle D M and Madhavan V 1999 Precise ${ }^{40} \mathrm{Ar} /{ }^{39} \mathrm{Ar}$ age determinations of the Kotakonda kimberlite and Chelima lamproite, India; implication for the mafic dyke swarm emplacement in the Eastern Dharwar craton; J. Geol. Soc. India $\mathbf{5 3}$ $425-432$

Christie J M, Griggs D T and Carter N L 1964 Experimental evidence of basal slip in quartz; J. Geol. 72 734-756.

Clauser C and Huenges E 1995 Thermal Conductivity of Rocks and Minerals; In: Rock Physics and Phase Relations - A Handbook of Physical Constants; American Geophysical Union Reference Shelf 3.

Clark S Jr (ed.) 1966 Thermal Conductivity; In: Handbook of Physical Constants; Geol. Soc. Amer. Mem. 97 459-482.

Clemens J D 1998 Observations on the origin and ascent mechanisms of granite Magmas; J. Geol. Soc. London $155843-851$.

Crawford A R and Compston W 1973 The age of the Cuddapah and Kurnool Systems, Southern India; J. Geol. Soc. Australia 19 (pt 4) 453-464.

Dobmeier C, Lütke S, Hammerschmidt K and Mezger K 2006 Emplacement and deformation of the Vinukonda meta-granite (Eastern Ghats, India) - Implications for the geological evolution of peninsular India and for Rodinia reconstructions; Precamb. Res. 146 165-178.

Etchecopar A 1977 A plane kinematic model of progressive deformation in a polycrystalline aggregate; Tectonophys. 39 121-139

Etheridge M A, Wall J and Vernon R H 1983 Role of the fluid phase during regional metamorphism and deformation; J. Metam. Geol. 1 205-226.

Fyfe W S, Price N J and Thompson A B 1978 Fluids in the earth's crust; Elsevier, Amsterdam, 383p.

Gapais D and Barbarin B 1986 Quartz fabric transition in a cooling syntectonic granite (Hermitage massif France); Tectonophys. 125 357-370.

Gleason G C, Tullis J and Heidelbach F 1993 The role of dynamic recrystallization in the development of lattice preferred orientations in experimentally deformed quartz aggregates; J. Struct. Geol. 15 1145-1168.

Gupta J N, Pandey B K, Chabria T, Banerjee D C and Jayaram K M 1984 Rb-Sr Geochronologic studies on the granites of Vinukonda and Kanigiri Prakasam district, Andhra Pradesh, India; Precamb. Res. 26 105-109.

Hippertt J F 1998 Breakdown of feldspar, volume gain and lateral mass transfer during mylonitization of granitoid in a low metamorphic grade shear zone; J. Struct. Geol. 20 175-193.

Hirth G and Tullis J 1992 Dislocation creep regimes in quartz aggregates; J. Struct. Geol. 14 145-159.

Hobbs B E, McLaren A C and Paterson M S 1972 Plasticity of single crystals of synthetic quartz; In: Flow and Fracture of Rocks; H C Heard, I Y Borg, N L Carter and C B Raleigh (eds) Geophysical Monograph 16 29-53.

Hutton D H W 1988 Granite emplacement mechanisms and tectonic controls; Inferences from deformation studies; Trans. Royal Soc. Edinburgh (Earth Sci.) 79 245-255.

Jessell M W and Lister G S 1990 A simulation of temperature dependence of quartz fabric; In: Deformation Mechanisms, Rheology and Tectonics; R J Knipe and E H Rutter (eds) Geol. Soc. Spec. Publ. 54 353-362.

Kruhl J H 1996 Prism- and basal-plane parallel subgrain boundaries in quartz: a microstructural geothermobarometer; J. Metam. Geol. 14 581-589.

Lister G S and Hobbs B E 1980 The simulation of fabric development during plastic deformation and its application to quartzite: The influence of deformation history; J. Struct. Geol. 2 355-370.

Lister G S, Paterson M S and Hobbs B E 1978 The simulation of fabric development in plastic deformation and its application to quartzite: the model; Tectonophys. $\mathbf{4 5}$ 107-158.

Mainprice D H, Bouchez J -L, Blumenfeld P and Tubia J M 1986 Dominance of c-slip in naturally deformed quartz: implication for dramatic plastic softening at high temperature; Geology 14 819-822.

Meijerink A M J, Rao D and Rupke J 1984 Stratigraphic and strucutural development of the Precambrian Cuddapah basin, SE India; Precamb. Res. 26 57-104.

Miller R B and Paterson S R 1994 The transition from magmatic to high-temperature solid-state deformation: implications from the Mount Stuart Batholith Washington; J. Struct. Geol. 16 853-865.

Nagaraja Rao B K, Rajurkar S T, Ramlingaswamy G and Ravindra Babu B 1987 Startigraphy, Strucutre and Evolution of the Cuddaph basin; In: Purana Basins of Peninsular India (Middle to Late Proterozoic); Geol. Soc. India Memoir. 6 33-86.

Narayanswami S 1966 Tectonics of the Cuddapah basin; J. Geol. Soc. India 7 33-50.

Nicolas A and Poirier J 1976 Crystal plasiticity and solid state flow in metamorphic rocks; (London: John Wiley \& Sons) 661p.

Pascoe E H 1973 A manual of the Geology of India and Burma vol. I ( $3^{\text {rd }}$ edition); Geological Survey of India, Calcutta, 485 p.

Paterson S R, Fowler T K Jr, Schmidt K L, Yoshinobu A S, Semele Yuan E and Miller R B 1998 Interpreting magmatic fabric pattern in plutons; Lithos 44 53-82.

Paterson S R and Tobisch O T 1992 Rates of processes in magmatic arcs: implications for the timing and nature of pluton emplacement and wall rock deformation; J. Struct. Geol. 14 291-300.

Paterson S R and Vernon R H 1995 Bursting the bubble of ballooning plutons: a return to nested diapirs emplaced by multiple processes; Bull. Geol. Soc. America $1071356-1380$

Paterson S R, Vernon R H and Tobisch O T 1989 A review of criteria for the identification of magmatic and tectonic foliations in granitoids; J. Struct. Geol. 11 349-363.

Pawley M J and Collins W J 2002 The development of contrasting structures during the cooling and crystallization of a syn-kinematic pluton; J. Struct. Geol. 24 469-483.

Pitcher W S 1997 The Nature and Origin of Granite, $2^{\text {nd }}$ edn. (London: Chapman \& Hall) 387 p. 
Pryer L L 1993 Microstructures in feldspars from a major crustal thrust zone: the Grenville Front, Ontario, Canada; J. Struct. Geol. 15 21-36.

Ramakrishnan M, Nanda J K and Augustine F 1998 Geological evolution of The Proterozoic Eastern Ghats Mobile Belt; Geol. Surv. India Spec. Publ. 44 1-21.

Ramam K and Murthy N 1997 Geology of Andhra Pradesh; Geol. Soc. India Bangalore, 245p.

Rogers J J W and Santosh M 2002 Configuration of Columbia: a Mesoproterozoic supercontinent; Gondwana Res. 5 5-22.

Saha D 2002 Multi-stage deformation in the Nallamalai Fold Belt: Cuddapah Basin, South India - implications for Mesoproterozoic tectonism along the southeastern margin of India; Gondwana Res. 5 701-719.

Saha D 2004 Structural asymmetry and plate tectonic set-up for a Proterozoic fold-and-thrust belt: Nallamalai fold belt and adjoining terrane, south India; In: Proceedings of the workshop on IGCP 453; Uniformitarianism revisited - comparison between ancient and modern orogens of India; Geol. Surv. India Spec. Publ. 84 $101-119$.

Saha D and Chakraborty S 2003 Deformation pattern in the Kurnool and Nallamalai Groups in the northeastern part (Palnad area) of the Cuddapah Basin: south India and its implication on Rodinia/Gondwana tectonics; Gondwana Res. 6 573-583.

Schmid S M and Casey M 1986 Complete fabric analysis of some commonly observed quartz $[c]$-axis patterns; In: Mineral and Rock Deformation: Laboratory Studies; B E Hobbs and H C Heard (eds) Geophysical Monograph 36 263-286.

Simpson C 1985 Deformation of granitic rocks across the brittle-ductile transition; J. $\quad$ Struct. Geol. 7 $503-511$.

Simpson C and Wintsch R 1989 Evidence for deformation induced K-feldspar replacement by myrmekite; J. Metam. Geol. 7 261-275.

Stipp M, Stunitz H, Heilbronner P and Schmid S M 2002 The eastern Tonale fault zone: a 'natural laboratory' for crystal plastic deformation of quartz over a temperature range from 250 to $700^{\circ}$ C; J. Struct. Geol. 24 1861-1884.

Streckeisen A 1976 To each plutonic rock its proper name; Earth Sci. Rev. 12 1-33.

Torgersen T 1990 Crustal-scale fluid transport: magnitude and mechanisms; Eos Transactions American Geophysical Union 71 1-1.

Trepmann C A and Stöckhert B 2003 Quartz microstructures developed during non-steady state plastic flow at rapidly decaying stress and strain rate; J. Struct. Geol. 25 2035-2051.

Tribe I R and D'Lemos R S 1996 Significance of a hiatus in down-temperature fabric development within syntectonic quartz diorite complexes, Channel Islands, UK; J. Geol. Soc. London 153 127-138.

Tullis J and Yund R A 1985 Dynamic recrystallization of feldspar - a mechanism for ductile shear zone formation; Geology 13 238-241.

Venkatakrishnan R and Dotiwala F E 1987 The Cuddapah salient: a tectonic model for the Cuddapah basin, India based on Landsat image interpretation; Tectonophys. 136 237-253.

Vernon R H 2000 Review of microstructural evidence of magmatic and solid-state flow; Electronic Geosciences 52.

Vigneresse J L 2006 Toward a new paradigm for granite generation; Trans. Roy. Soc. Edinburgh (Earth Sci.) 95 $11-22$.

Vigneresse J L, Barbey P and Cuney M 1996 Rheological transitions during partial melting and crystallization with application to felsic magma segregation and transfer; J. Petrol. 37 1579-1600.

Wibberley C 1999 Are feldspar-to-mica reactions necessarily reaction softening processes in fault zones? J. Struct. Geol. 21 1219-1227.

Wintsch R, Christoffersen R and Kronenberg A 1995 Fluidrock reaction weakening of fault zones; J. Geophys Res. 100 13021-13032.

Yardley B W D 1989 Introduction to Metamorphic Petrology; Longman, Essex 248p. 